\title{
Mothers with a History of Childhood Abuse Show Significant Bonding Impairments Towards their Infant
}

\author{
Eva Moehler* and Franz Resch \\ Department of Child and Adolescent Psychiatry, University of Heidelberg, Germany
}

Submission: September 12, 2018; Published: September 24, 2018

*Corresponding author: Eva Moehler, Department of Child and Adolescent Psychiatry, University of Heidelberg, Heidelberg, Germany, Email: eva.moehler@med.uni-heidelberg.de

\begin{abstract}
Maternal history of abuse has been proposed as a risk factor for child maltreatment but the background of this "cycle of abuse" is as yet poorly understood. As a contribution towards a deeper understanding of this phenomenon, this study analyzed whether maternal bonding is altered by maternal experiences of physical or sexual abuse during their upbringing. To form the index group, women who reached a cut-off for severe sexual and/or physical abuse in the Childhood Trauma Questionnaire and whose children were term babies with APGAR-Scores $>7$ were included in the study. Maternal bonding was compared with a group of mother-infant pairs matched for infant gender, maternal education, marital status, number of infants and birth weight. The results show that 12-month postnatal mothers with a history of physical or sexual abuse show a significant impairment of bonding towards their children. No impact of maternal abuse on child cognitive, motor and behavioral development in the first year was found. Impaired bonding patterns in mothers with a history of abuse should be considered as a potential risk factor for the offspring as well as for the future mother-infant relationship.
\end{abstract}

Keywords: Sexual abuse; Physical abuse; Child development; Mother-infant bonding; Child abuse

\section{Introduction}

Mother-infant bonding received scientific attention several decades ago [1] and its immense significance for child development has since then been frequently reproduced [2,3]. Social support and early contact have been described to promote mother-infant bonding. The methodology to assess mother-infant bonding however has been heterogeneous: video-observations [4] as well as clinical reports [5] are in use. In general intergenerational transmission of psychosocial risk can be regarded as a considerable threat to child development [6].

A parental history of childhood physical or sexual abuse is one of the most challenging factors for physical or sexual abuse of the offspring [7]. Mothers exposed to physical or sexual abuse in childhood are described in the literature as frequently closing the intergenerational cycle of violence either by maltreating their children or by becoming a victim and turning their children into perpetrators. Prevalence of a history of sexual abuse among young women is reported to be between $13 \%$ [8] and 25\% [9]. The numbers for physical abuse range from about $13 \%$ [8] to $40 \%$ [9]. To date, little is known about the mechanisms involved in the intergenerational transmission of abusive experiences. It has been proposed [10] that a general disturbance of empathy keeps former victims of violence from taking the child's perspective, thereby impairing parental perception of the child's needs. Projective distortions in relation to offspring have been postulated [10] as well as impairment of intrafamilial communication [11,12]. A recent three-generational study reported that approximately $50 \%$ of abused parents transmit a history of abuse to their offspring [13]. A parental history of abuse seems to be not a mandatory but a likely condition for child maltreatment.

Some authors [14] have stressed the importance of maternal postnatal depression or psychosocial factors when determining the risk of abuse. Also, it has been found that abused mothers rarely identify their infants' emotional signals correctly [15], and their empathic responsiveness and affective reactivity have been shown to be lowered [16]. As psychophysiological hyperactivity is a frequently described consequence of trauma $[17,18]$ hyperreactivity towards the infant might be postulated to play a role in the cycle of abuse. In general, background and development of early relational disturbance caused by a maternal history of abuse is as yet poorly understood. Observation and analysis of mother-infant interaction in critical dyads can and should be applied as an useful tool to identify early risk factors. Analysis of an abused mother's behavior and attitudes towards her own infant contributes to prevention and treatment of pervasive and severe interactional disturbances. Several studies have emphasized the importance of attachment disturbance for mediation of the 
intergenerational cycle of abuse [19,20]. Engfer and Gavranidou [21] described less maternal sensitivity in the neonatal period in mothers who were later found to abuse their infants. Insecure infant attachment has been shown to be associated with lower maternal sensitivity [22]. In order to analyze the question whether maternal bonding is involved in the intergenerational transmission of abusive experiences, we studied a sample of 58 mothers with a history of abuse in comparison to 61 mothers without such experiences.

\section{Method}

\section{Participants}

From October 2004 until February 2006 all women giving birth to a child in the cities of Heidelberg and Mannheim, Germany, were contacted by mail and presented with the Childhood Trauma Questionnaire (CTQ) [23,24]. Women whose children were singleton term babies ( $>37^{\text {th }}$ week) with Apgar-Score $>7$ were eligible for participation in the study. Twins and infants $<2500 \mathrm{~g}$ were excluded. Mothers who reached a cut-off-score for sexual and/or physical abuse were contacted and included in the study to form the index group. The control group was formed by matching mothers with none reported physical or/and sexual abuse experiences. Matching criteria-ordered in priorities -were: child gender, marital status, maternal education and number of children.

\section{Study design}

Mothers above the cut-off scores of the Childhood Trauma Questionnaire for physical and/or sexual abuse were invited for a laboratory visit with assessment of maternal bonding when their infants were five and 12 months old. Control mothers with a score of 0 on the physical and/or sexual abuse scale were matched according to infant gender, marital status, maternal education and number of children. The subjects were seen in the laboratory when the infant was five and again when it was 12 months of age. Pre- and perinatal data were documented before the assessment and infant health status was assessed. Mothers brought their infants to the laboratory during daytime, when their infants were alert, fed, and rested. All examiners were blinded with regard to maternal history or non-history of abuse.

\section{Measures}

\section{Postpartum bonding}

Maternal Bonding was assessed with the Postpartum Bonding Questionnaire. This questionnaire is designed by Brockington et al. [25] and has since been frequently applied to assess early disturbances in maternal bonding patterns. It consists of 25 items and has proven good test-retest reliability. The German version was created by translation and re-translation through officially licensed translators.

\section{Screening procedure and definition of abuse}

The history of physically or sexually abusive life experiences was assessed by the German version [24] of the Childhood Trauma Questionnaire (CTQ), developed by Bernstein and Fink
[23]. The CTQ has demonstrated strong psychometric properties in community samples [26] as well as in clinical samples [27]. The CTQ is a self-administered questionnaire with 28 items that quantifies the frequency of abusive experiences on a 5-point scale ranging from ' $1=$ never' to ' $5=$ =very often'. Different types of childhood trauma are operationalized on five subscales (emotional abuse, physical abuse, sexual abuse, emotional neglect, physical neglect). The subjects are asked to rate the frequency of abusive experiences during their childhood and adolescence. Cut-offscores have been determined to define the severity of the abusive experiences (none or minimal, minor, moderate, several) [23]. From the consecutive series of women, one group with a history of moderate or severe sexual and/or physical abuse and one group without any self-reported abusive experiences were selected. Women who reported a minor extent of physically and/or sexually abusive experiences were excluded.

\section{Covariate}

\section{Child developmental status}

Child Development was assessed via the Bayley Scales of Infant Development II according to Bayley [28] at a child's age of five (T1) and twelve (T2) months. This standardized instrument is an individually administered examination that assesses the current developmental functioning of infants and children- the main aim is to diagnose possible developmental delays. The Bayley Scales of Infant Development include three subscales: Motor Scale, Mental Scale and Behavior Rating Scale. The Mental and Motor Scales measure the infants' present stage of cognitive, language, personal-social, and fine and gross motor development. The child's behaviour during the testing is coded with the Behavior Rating Scale. The Mental Scale contains items that refer to memory, habituation, problem solving, early number concepts, generalization, classification, vocalizations, language and social skills. The Motor Scale measures the control of the gross and fine muscle groups and their functions: rolling, crawling and creeping, sitting, standing, walking, running and jumping; and supplementary fine motor handling involved in prehension, adaptive use of writing implements and the imitation of hand activities. The Mental and Motor Scale are nominal Dichotomy; The Behavior Rating Scale is an ordinal scale and allows to assess the child's development on a 5-point-scale, ranging from 1 (=worst coding) to 5 (=best coding). Two researchers trained for reliability independently observed the videotaped sessions for the Behavior Rating Scale; Cohen's' kappa was 0.93. Mental and Motor Scale were coded during the testing.

\section{Result}

\section{Sampling}

From 2.400 mothers contacted by mail 748 replied. Seventy eight mothers reached the cut-off-score for abusive sexual and/or physical experiences whereas ten had to be excluded due to their children did not fulfil the eligibility criteria. Four mothers had children with repeated infections or acute illnesses preventing them from participating and six mothers declined for lack of time. 
From the 675 mothers who scored below the cut-off for severe physical or sexual abuse, 417 mothers' scoring were excluded from the control group, because they scored in the intermediate group having experienced 'light' or 'moderate' abuse as measured by the Child Trauma Questionnaire [23]. Out of the remaining 258 mothers with a score for no sexual and/or physical abuse the matching was performed according to the already mentioned criteria: child gender, marital status, maternal education and number of children.

\section{Sample description}

The final sample consisted of 58 mothers with a history of abuse (HA-mothers; index group) and 61 control mothers (control group). The HA-mothers had 53\% male infants ( $n=31)$, the control mothers had $52 \%$ male children $(n=32)$. With regard to marital status $91.4 \%(n=53)$ of the HA-mothers were in a partnership with the child's father, while $100 \%(n=61)$ of the control mothers were in a partnership at the time of assessment. $74.4 \%(n=43)$ of the
HA-mothers were married, as were $85.2 \%(n=52)$ of the control group. $31 \%(n=18)$ of the HA-mothers had university degree; $36.1 \%(n=22)$ of the control mothers had university degree. Mean number of children in the trauma group was 1.7, in the control group 1.8 .

\section{History of abuse and postpartum bonding}

Index mothers had a mean Bonding Impairment Score of $13.64(\mathrm{SD}=8.4)$, control mothers had a score of $9.5(\mathrm{SD}=5.5)$. The difference was statistically significant $\left(\mathrm{LR}^{2}=6.81, \mathrm{p}=0.002\right.$, $\mathrm{F}=10.18$ ) as shown in Table 1.

Table 1: Mothers with abusive and non-abusive history in connection to their children's development at 5 months of age.

\begin{tabular}{|c|c|c|c|c|c|c|}
\hline PBQ & Group & $\mathbf{n}$ & $\mathbf{p}$ & $\mathbf{M}$ & SD & df \\
\hline \multirow{3}{*}{} & Index & 47 & \multirow{2}{*}{0.002} & 13.64 & 8.43 & \multirow{2}{*}{93} \\
\cline { 2 - 3 } \cline { 5 - 7 } & Control & 48 & & 9.52 & 5.48 & \\
\hline
\end{tabular}

\section{History of abuse and development of the child}

Table 2: Mothers with abusive and non-abusive history in connection to their children's development at five months of age (T1).

\begin{tabular}{|c|c|c|c|c|c|c|}
\hline T1 & Group & $\mathbf{n}$ & $\mathbf{p}$ & M & SD & df \\
\hline \multirow{2}{*}{ Motor Scale } & Index & 58 & \multirow{2}{*}{0.856} & 94.53 & 10.43 & \multirow{2}{*}{117} \\
\hline & Control & 61 & & 95.25 & 9.06 & \\
\hline \multirow{2}{*}{ Mental Scale } & Index & 58 & \multirow{2}{*}{0.869} & 99.66 & 10.08 & \multirow{2}{*}{117} \\
\hline & Control & 61 & & 100.61 & 7.87 & \\
\hline \multirow{2}{*}{ Behavior Rating Scale } & Index & 58 & \multirow{2}{*}{0.999} & 78.47 & 7.75 & \multirow{2}{*}{116} \\
\hline & Control & 61 & & 78.47 & 7.29 & \\
\hline
\end{tabular}

Table 3: Mothers with abusive and non-abusive history in connection to their children's development at 12 months of age (T2).

\begin{tabular}{|c|c|c|c|c|c|c|}
\hline T2 & Group & $\mathbf{n}$ & $\mathbf{p}$ & $\mathbf{M}$ & SD & df \\
\hline \multirow{2}{*}{ Motor Scale } & Index & 58 & \multirow{2}{*}{0.778} & 91.21 & 13.88 & \multirow[b]{2}{*}{117} \\
\hline & Control & 61 & & 91.89 & 12.27 & \\
\hline \multirow{2}{*}{ Mental Scale } & Index & 58 & \multirow{2}{*}{0.304} & 105.67 & 8.23 & \multirow{2}{*}{117} \\
\hline & Control & 61 & & 104.02 & 9.20 & \\
\hline \multirow{2}{*}{ Behavior Rating Scale } & Index & 58 & \multirow{2}{*}{0.907} & 128.12 & 14.86 & \multirow{2}{*}{117} \\
\hline & Control & 61 & & 128.43 & 13.72 & \\
\hline
\end{tabular}

The group testing of child developmental status, comparing the development of children of abused and not abused mothers, does not show significant results throughout all testing times. At an age of five months and twelve months the children of mothers with an abusive history do not significantly differ from the children of the control group mothers throughout all subscales of the Bayley Scales of Infant Development II. Niveau of significance, Means and Standard Deviation for the five months (T1) testing are listed in Table $2 \& 3$ presents those for the twelve months (T2) testing. The data show that children of mothers with a history of abuse do not significantly differ by mental, motor or behavioral development from children of mothers without a history of abuse.

\section{Discussion}

The data presented above indicate an association between maternal history of abuse and maternal bonding in the motherchild relationship. Mothers with abusive experiences show a considerable impairment of bonding in the first year of life compared to control mothers. This was mediated neither by infant gender, maternal marital status, education, nor number of children, as mothers in the control group were matched for these criteria. Psychosocial support in general has also been found to be protective for at-risk dyads [29]. However, mothers in our study did not differ from control mothers with regard to their psychosocial support, because of the matching criteria. The heightened 
bonding impairment reported here therefore is not likely to be an epiphenomenon of altered psychosocial circumstances. It might rather be regarded as a specific consequence of early life trauma reflecting itself into the next generation. This finding does not prove a heightened risk for child abuse from the side of the abused mother, but it does show a discrete aspect or precursors of child maltreatment, as this can be reflected by interactional alterations [30].

These data are in line with a primate study describing maternal possessiveness of the infant as a consequence of abuse in monkeys [31], potentially implicating a biological basis. On this line of reasoning maternal psychophysiological hyperreactivity might be a relevant factor underlying increased bonding impairment. Bauer and Twentyman [32] found a general hyperarousal and reactivity of abusive mothers, especially when they were interacting with their children. Also, mothers with a history of abuse have been described to show hyperreactivity to infant stimuli [33]. The same phenomenon has previously been reported in mothers who had been found to abuse their children [34]; therefore the relational alterations presented here might be related to psychophysiological alterations.

According to Egeland and coworkers [35], the transmission of abusive experiences can be prevented by a supportive marital relationship. Similarly, the cycle of abuse can be interrupted by the integration, as opposed to the dissociation, of the traumatizing events [36]. In a next step it should be analyzed whether dissociation is related to maternal bonding, as measured by the PBQ. This might be likely, as dissociation has been described as a common epiphenomenon of traumatic or abusive experiences $[37,38]$.

\section{Limitations}

This study did not perform clinical interviews to screen for clinical diagnoses such as borderline personality disorders, which have been frequently described to be associated with a history of abuse [37]. Also, maternal self-esteem, a relevant factor in psychopathology related to abusive experiences [39] was not measured. These factors should be considered in future studies. However, this study was based in the general population and the only manifest difference between the mothers was the history of physical and/or sexual abuse, as psychosocial status was carefully matched. Therefore the elevated bonding impairment identified here is likely to reflect a true impact of the history of intrusive trauma on the part of the mother.

\section{Clinical Relevance}

These data are highly relevant from a preventive point of view: Psychosocial support in general was found to be protective for at risk-dyads [40]. According to Brayden and co-workers [41] the risk for child maltreatment can be significantly lowered by reducing the time span that mother and infant are exposed to each other. Our data show that preventive efforts should not be limited to these general issues. Rather, preventive efforts in mothers with a history of abuse should target mother-infant interaction at a very early level, before the manifestation of overt child abuse. The findings reported here identify targets for these preventive efforts, as interaction with the mother constitutes a considerable part of the infant's environment, and therefore maternal intrusiveness can be regarded as having a profound influence on the infant life experiences. Cerebral plasticity in the first year of life is high [42], therefore preventive interventions should be most effective when targeting this period. Bonding Impairment therefore can be regarded as a target for studies focusing on factors that are relevant for intergenerational transmission of abusive experiences. Furthermore, these data identify the Postpartum Bonding Questionnaire as an important clinical tool for at-risk dyads. This research on young mothers with a history of sexual and physical abuse is crucial [35] in order to develop preventive strategies against the "cycle of abuse" and thereby highly important from an individual [43], social, and political perspective [44-62] (Appendix 1\&2).

Appendix 1: Postpartum Bonding Questionnaire Brockington et al. [25], German version by Weiss, Reck \& Fuchs) Wie es mir mit meinem Kind geht. Bitte kreuzen Sie an, wie häufig die folgenden Aussagen auf Sie zutreffen. Es gibt keine "falschen“ oder „richtigen“ Antworten; wählen Sie die

Antwort, die Ihrer Meinung nach am besten zutrifft.

\begin{tabular}{|c|c|c|c|c|c|c|}
\hline Name & \multicolumn{6}{|c|}{ Datum: Immer } \\
\hline Ich fühle mich meinem Kind sehr nahe. & 0 & 0 & 0 & 0 & 0 & 0 \\
\hline Ich wünsche mir die Zeiten ohne das Kind zurück. & 0 & 0 & 0 & 0 & 0 & 0 \\
\hline Ich fühle mich fern von meinem Kind. & 0 & 0 & 0 & 0 & 0 & 0 \\
\hline Ich kuschele gerne mit meinem Kind. & 0 & 0 & 0 & 0 & 0 & 0 \\
\hline Ich bedaure es, dieses Kind zu haben. & 0 & 0 & 0 & 0 & 0 & 0 \\
\hline Das Kind scheint nicht zu mir zugehören. & 0 & 0 & 0 & 0 & 0 & 0 \\
\hline Mein Kind strengt mich an. & 0 & 0 & 0 & 0 & 0 & 0 \\
\hline Mein Kind macht mich nervös. & 0 & 0 & 0 & 0 & 0 & 0 \\
\hline Ich fühle mich glücklich, wenn mein Kind lächelt oder lacht. & 0 & 0 & 0 & 0 & 0 & 0 \\
\hline Ich liebe mein Kind über alles. & 0 & 0 & 0 & 0 & 0 & 0 \\
\hline Ich genieße es, mit meinem Kind zu spielen. & 0 & 0 & 0 & 0 & 0 & $\mathrm{O}$ \\
\hline
\end{tabular}




\section{Journal of Gynecology and Women's Health}

\begin{tabular}{|c|c|c|c|c|c|c|}
\hline Mein Kind schreit zu viel. & 0 & 0 & 0 & 0 & 0 & 0 \\
\hline Als Mutter fühle ich mich gefangen. & 0 & 0 & 0 & 0 & 0 & 0 \\
\hline Ich bin böse auf mein Kind. & 0 & 0 & 0 & 0 & 0 & 0 \\
\hline Ich hege Groll gegen mein Kind. & 0 & 0 & 0 & 0 & 0 & 0 \\
\hline Mein Kind ist das schönste Kind der Welt. & 0 & 0 & 0 & 0 & 0 & 0 \\
\hline Ich wünschte, mein Kind würde irgendwie verschwinden. & 0 & 0 & 0 & 0 & 0 & 0 \\
\hline Ich habe mein Kind schlecht behandelt. & 0 & 0 & 0 & 0 & 0 & 0 \\
\hline Mein Kind macht mich unruhig. & 0 & 0 & 0 & 0 & 0 & 0 \\
\hline Ich habe Angst vor meinem Kind. & 0 & 0 & 0 & 0 & 0 & 0 \\
\hline Mein Kind fällt mir lästig. & 0 & 0 & 0 & 0 & 0 & 0 \\
\hline Ich fühle mich sicher, wenn ich mein Kind wickle. & 0 & 0 & 0 & 0 & 0 & 0 \\
\hline \multicolumn{7}{|l|}{ Ich glaube, die einzige Lösung ist, dass } \\
\hline jemand anderes nach meinem Kind zu schaut. & 0 & 0 & 0 & 0 & 0 & 0 \\
\hline Ich möchte meinem Kind weh tun. & 0 & 0 & 0 & 0 & 0 & 0 \\
\hline Mein Kind ist leicht zufriedenzustellen. & 0 & 0 & 0 & 0 & 0 & 0 \\
\hline
\end{tabular}

\section{CTQ}

\section{Anleitung}

Diese Fragen befassen sich mit einigen Ihrer Erfahrungen während Ihrer Kindheit und Jugend. Auch wenn die Fragen sehr persönlich sind, versuchen Sie bitte, sie so ehrlich wie möglich zu beantworten. Kreisen Sie dazu bitte für jede Frage die Zahl ein, die am besten beschreibt, wie Sie rückblickend die Situation einschätzen.

\section{Antwortbeispiel: $\quad 1 \quad 23445$}

Appendix 2: Childhood Trauma Questionnaire (CTQ): Bernstein and Fink [23], German version by Driessen et al. [24].

\begin{tabular}{|c|c|c|c|c|c|c|}
\hline \multirow[b]{3}{*}{1} & \multirow[t]{2}{*}{ Als Ich Aufwuchs... } & \multicolumn{5}{|c|}{ Trifft Auf Mich Zu... } \\
\hline & & \multicolumn{5}{|c|}{ Über-Haupt Nicht Sehr Selten Einige Male Sehr Häufig } \\
\hline & ...hatte ich nicht genug zu essen. & 1 & 2 & 3 & 4 & 5 \\
\hline 2 & ...wußte ich, daß sich jemand um mich sorgte und mich beschützte. & 1 & 2 & 3 & 4 & 5 \\
\hline 3 & $\begin{array}{l}\text {..bezeichneten mich Personen aus meiner Familie als „dumm“, „faul“ oder } \\
\text { „häßlich“. }\end{array}$ & 1 & 2 & 3 & 4 & 5 \\
\hline 4 & $\begin{array}{l}\text {...waren meine Eltern zu betrunken oder von anderen Drogen „high“, um für die } \\
\text { Familie zu sorgen. }\end{array}$ & 1 & 2 & 3 & 4 & 5 \\
\hline 5 & $\begin{array}{l}\text {...gab es jemand in der Familie, der mir das Gefühl gab, wichtig und jemand } \\
\text { Besonderes zu sein. }\end{array}$ & 1 & 2 & 3 & 4 & 5 \\
\hline 6 & ...mußte ich dreckige Kleidung tragen. & 1 & 2 & 3 & 4 & 5 \\
\hline 7 & ...hatte ich das Gefühl, geliebt zu werden. & 1 & 2 & 3 & 4 & 5 \\
\hline 8 & ...glaubte ich, daß meine Eltern wünschten, ich wäre nie geboren. & 1 & 2 & 3 & 4 & 5 \\
\hline 9 & $\begin{array}{l}\text {...wurde ich von jemandem aus meiner Familie so stark geschlagen, daß ich zum } \\
\text { Arzt oder ins Krankenhaus mußte. }\end{array}$ & 1 & 2 & 3 & 4 & 5 \\
\hline 10 & ...gab es nichts, was ich an meiner Familie ändern wollte. & 1 & 2 & 3 & 4 & 5 \\
\hline 11 & $\begin{array}{c}\begin{array}{c}\text {...schlugen mich Personen aus meiner Familie so stark, daß ich blaue Flecken } \\
\text { oder Schrammen davontrug. }\end{array}\end{array}$ & 1 & 2 & 3 & 4 & 5 \\
\hline 12 & $\begin{array}{l}\begin{array}{l}\text {...wurde ich mit einem Gürtel, einem Stock, einem Riemen oder mit einem har- } \\
\text { ten Gegenstand bestraft. }\end{array} \\
\end{array}$ & 1 & 2 & 3 & 4 & 5 \\
\hline 13 & meine Familienangehörigen aufeinander acht. & 1 & 2 & 3 & 4 & 5 \\
\hline 14 & $\begin{array}{l}\text {...sagten Personen aus meiner Familie verletzende oder beleidigende Dinge zu } \\
\text { mir. }\end{array}$ & 1 & 2 & 3 & 4 & 5 \\
\hline 15 & Ich glaube, ich bin körperlich mißhandelt worden, als ich aufwuchs. & 1 & 2 & 3 & 4 & 5 \\
\hline 16 & ...hatte ich eine perfekte Kindheit. & 1 & 2 & 3 & 4 & 5 \\
\hline
\end{tabular}




\section{Journal of Gynecology and Women's Health}

\begin{tabular}{|c|c|c|c|c|c|c|}
\hline 17 & $\begin{array}{l}\begin{array}{l}\text {...wurde ich so stark geschlagen oder verprügelt, daß es jemandem (z.B. Lehrer, } \\
\text { Nachbar oder Arzt) auffiel. }\end{array}\end{array}$ & 1 & 2 & 3 & 4 & 5 \\
\hline 18 & ...hatte ich das Gefühl, es haßte mich jemand in meiner Familie. & 1 & 2 & 3 & 4 & 5 \\
\hline 19 & ...fühlten sich meine Familienangehörigen einander nah. & 1 & 2 & 3 & 4 & 5 \\
\hline 20 & $\begin{array}{l}\text {...versuchte jemand, mich sexuell zu berühren oder mich dazu zu bringen, sie } \\
\text { oder ihn sexuell zu berühren. }\end{array}$ & 1 & 2 & 3 & 4 & 5 \\
\hline 21 & $\begin{array}{l}\text {...drohte mir jemand, mir weh zu tun oder Lügen über mich zu erzählen, wenn } \\
\text { ich keine sexuellen Handlungen mit ihm oder ihr ausführen würde. }\end{array}$ & 1 & 2 & 3 & 4 & 5 \\
\hline 22 & ...hatte ich die beste Familie der Welt. & 1 & 2 & 3 & 4 & 5 \\
\hline 23 & $\begin{array}{c}\text {...versuchte jemand, mich dazu zu bringen, sexuelle Dinge zu tun oder bei sexu- } \\
\text { ellen Dingen zuzusehen. }\end{array}$ & 1 & 2 & 3 & 4 & 5 \\
\hline 24 & ...belästigte mich jemand sexuell. & 1 & 2 & 3 & 4 & 5 \\
\hline 25 & $\begin{array}{l}\text { Ich glaube, ich bin emotional (gefühlsmäßig) mißbraucht worden, als ich } \\
\text { aufwuchs. }\end{array}$ & 1 & 2 & 3 & 4 & 5 \\
\hline 26 & ...gab es jemanden, der mich zum Arzt brachte, wenn ich es brauchte. & 1 & 2 & 3 & 4 & 5 \\
\hline 27 & Ich glaube, ich bin sexuell mißbraucht worden, als ich aufwuchs. & 1 & 2 & 3 & 4 & 5 \\
\hline 28 & ...war meine Familie mir eine Quelle der Unterstützung. & 1 & 2 & 3 & 4 & 5 \\
\hline 29 & ...geschahen unerwartete und unvorhersehbare Dinge in meiner Familie. & 1 & 2 & 3 & 4 & 5 \\
\hline 30 & $\begin{array}{l}\text {...waren meine Eltern (Stiefeltern) oder andere Personen aus meiner Familie } \\
\text { unberechenbar. }\end{array}$ & 1 & 2 & 3 & 4 & 5 \\
\hline 31 & ...befürchtete ich, daß meine Familie jederzeit auseinanderbrechen könnte. & 1 & 2 & 3 & 4 & 5 \\
\hline 32 & ...konnte ich mich in meiner Familie nicht sicher fühlen. & 1 & 2 & 3 & 4 & 5 \\
\hline 33 & ...wechselten die Mitglieder meiner Familie. & 1 & 2 & 3 & 4 & 5 \\
\hline 34 & ...konnte ich mich auf Personen aus meiner Familie nicht verlassen. & 1 & 2 & 3 & 4 & 5 \\
\hline
\end{tabular}

\section{References}

1. Klaus MH, Kennell JH (1976) Maternal-Infant Bonding. St Louis: Mosby, USA.

2. Eyer DE (1994) Mother-infant bonding: A scientific fiction. Human Nature 5(1): 69-94

3. Goldberg S (1983) Parent-infant bonding: Another look. Child Development 54(6): 1355-1382.

4. Anisfeld E, Lipper E (1983) Early Contact, Social Support, and MotherInfant Bonding. Pediatrics 72(1): 79-83.

5. Kumar RC (1997) 'Anybody's child': Severe disorders of mother-toinfant bonding. Br J Psychiatry 171: 175-181.

6. Bifulco A, Moran PM, Ball C, Jacobs C, Baines R, et al. (2002) Childhood adversity, parental vulnerability and disorder: examining intergenerational transmission of risk. J Child Psychol Psychiatry 43(8) 1075-1086.

7. Sidebotham P, Golding J (2001) ALSPAC Study Team. Avon longitudinal study of parents and children. Child maltreatment in the "children of the nineties" a longitudinal study of parental risk factors. Child Abuse \& Neglect 25(9): 1177-1200.

8. Kessler RC, Sonnega A, Bromet E, Hughes M, Nelson C, et al. (1995) Posttraumatic stress disorder in the national comorbidity survey. Archives of General Psychiatry 52(12): 1048-1060.

9. Goodman L, Corcoran C, Turner K, Yuan N, Green B, et al. (1998) Assessing traumatic event exposure: General issues and preliminary findings for the Stressful Life Events Screening Questionnaire. J Trauma Stress 11(3): 521-542.
10. Moehler E, Resch F, Cierpka A, Cierpka M (2001) The early appearance and intergenerational transmission of maternal traumatic experiences in the context of mother-infant interaction. Journal of Child Psychotherapy 27(3): 257-271.

11. Farmularo R, Kinscherff R, Fenton T (1992) Psychiatric diagnoses of abusive mothers: a preliminary report. Journal of Nervous \& Mental Disease 180(10): 658-661.

12. Ratzke K, Cierpka M (1991) Familien von Kindern mit aggressiven Verhaltensweisen. In: U Engle, S Hoffmann, P Joraschky, P Schattauer (eds.) Sexueller Mißbrauch, Mißhandlung, Vernachlässigung. Stuttgart, New York: Publisher, USA

13. Leifer M, Kilbane T, Jacobsen T, Grossman G (2004) A three-generational study of transmission of risk for sexual abuse. J Clin Child Adolesc Psychol 33(4): 662-672.

14. Cadzow SP, Armstrong KL, Fraser JA (1999) Stressed parents with infants: Reassessing physical abuse risk factors. Child Abuse \& Neglect 23(9): 845-853.

15. Kropp JP, Haynes OM (1987) Abusive and nonabusive mothers' ability to identify general and specific emotion signals of infants. Child Dev 58(1): 187-190

16. Milner JS, Hlasey LB, Fultz J (1995) Empathic responsiveness and affective reactivity to infant stimuli in high- and low-risk for physical child abuse mothers. Child Abuse \& Neglect 19(6): 767-780.

17. Shalev AY, Peri T, Brandes D, Freedman S (2000) Auditory startle response in patients with posttraumatic stress disorder: A prospctive study. American Journal of Psychiatry 157(2): 255-261. 
18. Van der Kolk BA (1997) The Psychopbiology of posttraumatic stress disorder. Journal of Clinical Psychiatry 58(suppl9): 16-24.

19. Crittenden PM, Patridge M, Claussen AH (1991) Family patterns of relationship informative and dysfunctional families. Developmental Psychopathology 3: 491-512.

20. Liang B, Williams LM, Siegel JA (2006) Relational outcomes of childhood sexual trauma in female survivors: A longitudinal study. Journal of Interpersonal Violence 21(1): 42-57.

21. Engfer A, Gavranidou M (1987) Antecedents and consequences of maternal sensitivity. A longitudinal study. In: H Rauh, HC Steinhausen (Ed.) Psychobiology and early development. North-Holland, Elsevier pp. 71-99.

22. Ziv Y, Gini M, Sagi A, Koren-Karie N (1997) Dyadic emotional availability and quality of mother-infant attachment: A three point longitudinal study. Paper presented at the meeting of the Society for Research in child development, Washington, DC, USA.

23. Bernstein DP, Fink LF (1999) Childhood Trauma Questionnaire (CTQ). Psychological Corporation, San Antonio, TX, USA.

24. Driessen M, Herrmann J, Stahl K, Zwaan M, Meier S, et al. (2000) Magentic resonance imaging volumes of the hippocampus and the amygdala in women with borderline personality disorder and early traumatization. Arch Gen Psychiatry 57(12): 1115-1122.

25. Brockington IF, Oates J, George S, Turner D, Vostanis P, et al. (2001) A Screening Questionnaire for mother-infant bonding disorders. Archives of Women's Mental Health 3(4): 133-140.

26. Scher CD, Stein MB, Asmundson GJ, McCreary DR, Forde DR, et al (2001) The childhood trauma questionnaire in a community sample: Psychometric properties and normative data. J Trauma Stress 14(4) 843-857.

27. Bernstein DP, Stein JA, Newcomb M, Walker E, Pogge D, et al. (2003) Development and validation of a brief screening version of the Childhood Trauma (CTQ). Child Abuse\& Neglect 27(2): 169-190.

28. Bayley N (1993) Bayley Scales of Infant Development. In: ( $2^{\text {nd }}$ edn) The Psychological Corporation, San Antonio, USA.

29. Crittenden PM (1981) Abusing, neglecting, problematic, and adequate dyads: Differentiating by patterns of interaction. Merrill-Palmer Quarterly 27(3): 201-218.

30. Garbarino J (1993) Psychological child maltreatment. Prim Care 20(2): 307-315.

31. Troisi A, D'Amato FR (1984) Ambivalence in monkey mothering Infant abuse combined with maternal possessiveness. J Nerv Ment Dis 172(2): 105-108.

32. Bauer WD, Twentyman CT (1985) Abusing, neglectful and comparison mothers' responses to child-related and non-child-related stressors. Journal of Consulting \& Clinical Psychology 53(3): 335-343.

33. Casanova GM, Domanic J, McCanne TR, Milner JS (1994) Physiological responses to child stimuli in mothers with and without a childhood history of physical abuse. Child Abuse \& Neglect 18(12): 995-1004.

34. Casanova GM, Domanic J, McCanne TR, Milner JS (1992) Physiological responses to non-child-related stressors in mothers at risk for child abuse. Child Abuse \& Neglect 16(1): 31-44.

35. Egeland B, Jacobvitz D, Sroufe LA (1988) Breaking the cycle of abuse Child Development 59(4): 1080-1088.

36. Egeland B, Susman-Stillman A (1996) Dissociation as a mediator of child abuse across generations. Child Abuse Negl 20(11): 1123-1132.

37. Ogata S, Silk KR, Goodrich S, Lohr NE, Westen D, et al. (1990) Childhood sexual and physical abuse in adult patients with borderline personality disorder. Am J Psychiatry 147(8): 1008-1013.
38. Kirby JS, Chu JA, Dill DL (1993) Correlates of dissociative symptomatology in patients with physical and sexual abuse histories. Comprehensive Psychiatry 34(4): 258-263.

39. Oates RK, Forrest D (1984) Self-esteem and early background of abusive mothers. Child Abuse Negl 9(1): 89-93.

40. Bishop SJ, Leadbeater BJ (1999) Maternal social support patterns and child maltreatment: Comparison of maltreating and nonmaltreating mothers. American Journal of Orthopsychiatry 69(2): 172-181.

41. Brayden RM, Altemeier WA, Tucker DD, Dietrich MS, Vietze P, et al. (1992) Antecedents of child neglect in the first two years of life. Journal of Pediatrics 120(3): 426-429.

42. Herschkowitz N (2000) Neurological bases of behavioural development in infancy. Brain Dev 22(7): 411-416.

43. Croghan R, Miell D (1999) Born to abuse? Negotiating identity within an interpretative repertoire of impairment. British Journal of Social Psychology 38(3): 315-335.

44. Metzger LJ, Orr SP, Berry NJ, Ahern CE (1999) Physiological responsiveness in women with posttraumatic stress disorder. Journal of Abnormal Psychology 108(2): 45- 361.

45. Oliver JE (1993) Intergenerational transmission of child abuse: Rates, research and clinical implications. Am J Psychiatry 150(9): 1315-1324.

46. Paris J, Zweig-Frank H (1992) A critical review of the role of childhood sexual abuse in the etiology of borderline personality disorder. Can J Psychiatry 37(2): 125-128.

47. Paris J, Zweig-Frank H, Guzder H (1994) Psychological risk factors for borderline personality disorders in female patients. Compr Psychiatry 35(4): 301-305.

48. Posner MI, Rothbarth MK (1980) The development of attentional mechanisms. Nebraska Symposium on Motivation 28: 1-52.

49. Pressman LJ, Pipp-Siegel S, Yoshinga-Itano C, Deas A (1999) Maternal sensitivity predicts language gain in preschool children who are deaf and hard of hearing. J Deaf Stud Deaf Educ 4(4): 294-304.

50. Sagi A, Tirosh E, Ziv Y, Guttman S, Lavie P, et al. (1998) Attachment and sleep patterns in the first year of life. Paper presented at the International Conference on Infant Studies, Atlanta, GA.

51. Kolk VDBA, Perry JC, Herman JL (1991) Childhood origins of selfdestructive behaviour. Am J Psychiatry 148(12): 1665-1671.

52. Zeanah CH, Scheeringa M, Boris NW, Heller SS, Smyke AT, et al. (2004) Reactive attachment disorder in maltreated toddlers. Child Abuse Negl 28(8): 877-888.

53. Ziv Y, Aviezer O, Gini M, Sagi A, Koren-Karie N, et al. (2000) Emotional availability in the mother-infant dyad as related to the quality of infantmother attachment relationship. Attachment \& Human Development 2(2): 149-169.

54. Crittenden PM, DiLalla DL (1988) Compulsive compliance: The development of an inhibitory coping strategy in infancy. J Abnorm Child Psychol 16(5): 585-599.

55. Cierpka M, Cierpka A (1997) Die Identifikation eines mißbrauchten Kindes. Psychotherapeut 42: 98-105.

56. Chu JA, Dill DL (1990) Dissociative symptoms in relation to childhood physical and sexual abuse. Am J Psychiatry 147(7): 887-892.

57. Carter AS, Little C, Garrity-Rokous FE (1998) Adapting the emotional availability Sales for four month old infant-parent dyads: Association with molecular coding and parental psychopathology. In: Z. Biringen (ed.) Emotional availability, risk and attachment. Symposium conducted at the International Conference on Infant Studies, Atlanta, Georgia. 
58. Buist A (1998) Childhood abuse, parenting and postpartum depression. Australian \& New Zealand Journal of Psychiatry 32: 479-487.

59. Brown J, Cohen P, Johnson JG, Salzinge S (1998) A longitudinal analysis of risk Factors for child maltreatment: Findings of a 17-year prospective study of officially recorded and self-reported child-abuse and neglect. Child Abuse Negl 22(11): 1065-1078.

60. Brazelton TB, Cramer BG (1991) Die frühe Bindung: die erste Beziehung zwischen dem Baby und seinen Eltern. Stuttgart: Klett-Cotta, Germany.
61. Biringen Z, Robinson JL (1991) Emotional availability: A reconceptualization for research. Am J Orthopsychiatry 61(2): 258271.

62. Aviezar O, Sagi A, Joels T, Ziv Y (1999) Emotional availability and attachment representations in kibbutz infants and their mothers. Developmental Psychology 35(3): 811-821.

\section{Your next submission with Juniper Publishers will reach you the below assets}

- Quality Editorial service

- Swift Peer Review

- Reprints availability

- E-prints Service

- Manuscript Podcast for convenient understanding

- Global attainment for your research

- Manuscript accessibility in different formats

( Pdf, E-pub, Full Text, Audio)

- Unceasing customer service

Track the below URL for one-step submission https://juniperpublishers.com/online-submission.php 